\title{
Anti-inflammatory Antibody ALXN1007
}

National Cancer Institute

\section{Source}

National Cancer Institute. Anti-inflammatory Antibody ALXN1007. NCI Thesaurus. Code C118441.

A proprietary antibody that targets the complement inflammatory pathway with potential immunomodulating and anti-inflammatory activities. Upon intravenous administration, anti-inflammatory antibody ALXN1007 modulates the complement inflammatory pathway through binding to an as of yet undisclosed target. This may help in the treatment of certain inflammatory-mediated disorders, such as antiphospholipid syndrome (APS). This agent may also influence the progression of graft-versus-host disease (GvHD). 